\title{
Altered antibody pattern to Epstein-Barr virus but not to other herpesviruses in multiple sclerosis: a population based case-control study from western Norway
}

\author{
Kjell-Morten Myhr, Trond Riise, Elizabeth Barrett-Connor, Helge Myrmel,
} Christian Vedeler, Marit Grønning, May Britt Kalvenes, Harald Nyland

\section{Department of \\ Neurology \\ K-M Myhr \\ C Vedeler \\ M Grønning \\ $\mathrm{H}$ Nyland}

Department of Public Health, Division for Occupational Medicine T Riise

Department of Microbiology and Immunology

H Myrmel

Department of Pathology, The Gade Institute, University of Bergen, 5021 Bergen, Norway

M B Kalvenes

Department of Family and Preventive

Medicine, School of

Medicine, University

of California, San

Diego, USA

E Barrett-Connor

Correspondence to:

Dr Kjell-Morten Myhr,

Department of Neurology,

Haukeland Hospital,

University of Bergen, 5021

Bergen, Norway. Telephone

004755974500 ; fax 0047

55975164 .

Received 16 June 1997 and in revised form 4 September 1997

Accepted 17 September 1997

\begin{abstract}
Objective-The prevalence of anti-EBV antibodies was studied in a group of 144 patients with multiple sclerosis and 170 age, sex, and area matched controls from the county of Hordaland, western Norway. The prevalence of three other herpesviruses, herpes simplex virus (HSV), varicella zoster virus (VZV), and cytomegalovirus (CMV), were also included.

Methods-Antibodies to various virus antigens were determined by enzyme linked immunosorbent assay (ELISA) and indirect immunfluorescence (IIF) in serum samples from 144 patients with multiple sclerosis and 170 controls.

Results-All of the 144 patients with multiple sclerosis had IgG antibodies to EBV compared with 162 of 170 controls $(p=0.008)$. The frequency of IgG antibodies to EBV capsid antigen (VCA), nuclear antigen (EBNA), and early antigen (EA) was significantly higher in patients with multiple sclerosis compared with the controls $(\mathrm{p}<0.000001, \mathrm{p}=0.01$, and $\mathrm{p}<0.0001$ respectively). The presence of antibodies was independent of the initial course of the disease and the disease activity at the time of blood sampling. The prevalence of IgG antibodies to HSV, CMV, and VZV did not differ between cases and controls.

Conclusion-The results suggest a role for EBV in the aetiology of multiple sclerosis. (F Neurol Neurosurg Psychiatry 1998;64:539-542)
\end{abstract}

Keywords: multiple sclerosis; Epstein-Barr virus; herpesvirus; antibodies

Multiple sclerosis is an inflammatory demyelinating disorder of the CNS. Although the aetiology is unknown, epidemiological studies suggest that infections during late childhood or early adolescence may predispose genetically susceptible people to later development of the disease. Numerous infectious agents, both viral and bacterial, have been suggested as being involved in the aetiology of multiple sclerosis, but so far no agent has been consistently associated with the disease.

Viruses that can establish persistent or latent infections in the CNS or the immune system are attractive candidates as aetiological agents in a chronic neurological disorder such as multiple sclerosis. Epstein-Barr virus (EBV) has this ability, ${ }^{2}$ and among various neurological complications, demyelinating disease has been found after primary EBV infection. ${ }^{34}$

Epidemiological evidence for an association between EBV and multiple sclerosis has also been reported. Increased risk of multiple sclerosis has been found in people with a history of infectious mononucleosis. ${ }^{5-8}$ The peak incidence for infectious mononucleosis is at the age of 15-25 years, with a mean age at 18 for males and 16 for females ${ }^{9}$ which is within the critical period of exposure to an exogenous factor suggested by several migration studies..$^{10-12}$ Further, some reports have shown a higher prevalence (99\%-100\%) of anti-EBV antibodies in patients with multiple sclerosis than in controls $(84-95 \%){ }^{13-17}$ Others have not been able to confirm these findings. ${ }^{18} 19$ Differences may reflect selection of patients or small numbers. None of the studies were population based. We have previously reported a raised EBV related autoimmune response in patients with multiple sclerosis $^{20}$ and clustering of places of residence of patients with multiple sclerosis at the ages of 13-20 years, ${ }^{21}$ which coincides with the ages of high incidence of infectious mononucleosis. ${ }^{9}$ In the present report, we have studied the seroprevalence of anti-EBV antibodies in the same group of patients with multiple sclerosis and controls from the county of Hordaland. The seroprevalence of three other herpesviruses, herpes simplex virus (HSV), varicella zoster virus (VZV), and cytomegalovirus (CMV), were also included.

\section{Materials and methods}

PATIENTS

All patients with multiple sclerosis within the county of Hordaland, western Norway and with clinical onset within that county, during the period 1976 to 1986 and diagnosed before 
Antibodies to herpesviruses among patients with multiple sclerosis and controls

\begin{tabular}{|c|c|c|c|c|c|c|}
\hline \multirow{3}{*}{$\begin{array}{l}\text { Virus/type of } \\
\text { antibody }\end{array}$} & \multicolumn{2}{|c|}{ MS positive (\%) } & \multicolumn{2}{|c|}{ Controls positive (\%) } & \multicolumn{2}{|c|}{$\begin{array}{l}\text { Test of difference between } \\
\text { groups }\end{array}$} \\
\hline & \multicolumn{2}{|c|}{$n=144$} & \multicolumn{2}{|c|}{$n=170$} & $O / R$ & $p$ Value \\
\hline & 141 & $(97.9)$ & 138 & $(81.2)$ & 10.90 & $<0.000001$ \\
\hline VCA-IgM & 2 & $(1.4)$ & $1^{\star}$ & $(0.7)$ & 1.99 & $0.57 \dagger$ \\
\hline EBNA-IgG & 143 & (99.3) & 160 & $(94.1)$ & 8.94 & 0.013 \\
\hline EA-IgG & 99 & $(68.8)$ & 79 & $(46.5)$ & 2.53 & $<0.0001$ \\
\hline Total $\ddagger$ & 144 & $(100)$ & 162 & (95.3) & - & 0.0084 \\
\hline HSV-IgG & 117 & (81.3) & 148 & $(87.1)$ & 0.64 & 0.16 \\
\hline VZV-IgG & 141 & (97.9) & 167 & $(98.2)$ & 0.84 & 0.84 \\
\hline CMV-IgG & 91 & $(63.2)$ & 117 & $(68.8)$ & 0.78 & 0.29 \\
\hline
\end{tabular}

*Test performed in 142 subjects.

†Fisher's exact test.

$\ddagger$ Tested positive to one or more EBV antigens.

$\mathrm{MS}=$ multiple sclerosis; $\mathrm{O} / \mathrm{R}=$ odds ratio; $\mathrm{EBV}=$ Epstein-Barr virus; $\mathrm{VCA}=$ viral capsid antigen; $\mathrm{EBNA}=$ Epstein-Barr virus nuclear antigen; $\mathrm{EA}=$ early antigen; $\mathrm{HSV}=$ herpes simplex virus; $\mathrm{VZV}=$ varicella zoster virus; $\mathrm{CMV}=$ cytomegalovirus.

1 January 1987, were selected for the study. The total of 144 patients comprised 61 men and 83 women, aged 17-66 years (mean age 39.2 years). According to the criteria of McAlpine, ${ }^{22} 130(90.3 \%)$ patients were classified as having definite multiple sclerosis, 10 $(6.9 \%)$ as having probable multiple sclerosis, and four $(2.8 \%)$ as having possible multiple sclerosis. Mean duration of disease was 6.9 years, range 1-11 years, and the initial course of the disease was relapsing-remitting in 117 $(81.2 \%)$ and primary progressive in 27 $(18.8 \%)$. Serum samples were collected in 1988 and $15(10.3 \%)$ of the patients were in acute relapse at the time of blood sampling.

\section{CONTROLS}

Controls comprised 170 patients admitted to hospital with traumatic fractures, traumatic rupture of ligaments, or minor gynaecological or plastic surgery disorders. There were 77 men and 93 women, aged 18-77 years (mean age 40.0 years) and they were category matched to the cases according to age (five year age groups), sex, and area of residence (inland, coastal, and urban area) that gave a similar distribution of cases and controls for these variables. Blood sampling was performed at the same time as for the patients.

ANTIBODY ANALYSIS

IgG and IgM antibodies to EBV viral capsid antigen (VCA) were determined by enzyme linked immunosorbent assay (ELISA) (Dupont, N Billerica, MA, USA) and indirect immunofluorescence (IIF) (Organon Teknika, Durham, NC, USA). IgG antibodies to EBV nuclear antigen (EBNA) and early antigen (EA) were measured by IIF (Organon Teknika, Durham, NC, USA). IgG antibodies to HSV, VZV, and CMV were determined by ELISA (Enzygnost, Behringwerke, Marburg, Germany). All assays included negative and positive controls.

\section{STATISTICAL ANALYSIS}

Comparisons were analysed by the $\chi^{2}$ method, or Fisher's exact test for small numbers. The odds ratio was used to estimate the risk of being a case given the presence of exposure. In addition, a multivariate logistic regression analysis was performed with sex and age as covariables to test for any residual effects of these variables. Significance was set at $\mathrm{p}<0.05$.

\section{Results}

The table shows that anti-VCA IgG antibodies were detected in $97.9 \%$ of the patients with multiple sclerosis and $81.2 \%$ of the controls $(\mathrm{p}<0.000001) . \operatorname{Ig} M$ antibodies to VCA were present in $1.4 \%$ of the patients with multiple sclerosis compared with $0.7 \%$ of the controls $(\mathrm{p}=0.57)$. IgG antibodies to EA were present in $68.8 \%$ of the patients with multiple sclerosis compared with $46.5 \%$ of the controls $(\mathrm{p}=0.00007)$.

Anti-EA antibodies were present in $71.8 \%$ of the patients with relapsing-remitting disease compared with $55.6 \%$ of the patients with primary progressive disease $(\mathrm{p}=0.10)$ and $10.7 \%$ of the anti-EA positive patients with relapsingremitting disease were in acute relapse at the time of blood sampling compared with $18.2 \%$ of the anti-EA negative patients with relapsingremitting disease $(p=0.28)$. Thus the anti-EA response was independent of the initial course of the disease and the disease activity at the time of blood sampling. IgG antibodies to EBNA were present in $99.3 \%$ of the patients with multiple sclerosis and $94.1 \%$ of the controls $(p=0.013)$. Only one patient was antiEBNA negative, but this patient tested positive for anti-VCA IgG antibodies. Thus all patients with multiple sclerosis $(100 \%)$ were antiEBNA or anti-VCA IgG positive compared with $162(95.3 \%)$ of the controls $(\mathrm{p}=0.008)$.

The table shows that patients and controls did not differ in the prevalence of antibodies to other herpesviruses (HSV, VZV, and CMV).

The controls were category matched to the cases according to age and sex. However, to test any residual effect of these variables a multivariate logistic regression analysis was performed with sex and age as covariables; these analyses presented only minor changes in odds ratios and $\mathrm{p}$ values.

\section{Discussion}

The presence of serum IgG antibodies to EBV EBNA, or VCA, or both, indicating a history of EBV infection, were present in all the patients with multiple sclerosis and were significantly more frequent than in the control population, confirming the results of previous studies. ${ }^{13-17}$ Further, a co-twin study has reported a higher frequency of anti-EBV IgG antibodies in the twins with multiple sclerosis compared with their healthy co-twins. ${ }^{23}$ Coyle et $a l^{19}$ have reported a higher frequency of anti-EBV antibodies in patients with multiple sclerosis (13 of 22) compared with controls (three of 12) although the numbers were small. The sensitivity of the test in this study was probably low because the prevalence of anti-EBV antibodies in the control group was much lower than expected..$^{13-17}$ Compston et $a l^{18}$ reported a lower prevalence of anti-EBV antibodies in the patient group $(76 \%)$ and controls $(73 \%)$. However, the patient group included patients with optic neuritis and isolated demyelinating lesions in addition to patients with clinically definite multiple sclerosis. Therefore this study 
is not readily comparable with the other studies with only patients with multiple sclerosis included. In addition Compston et al used other methods in their analysis (IIF) compared with the present study (ELISA) that could contribute to the different results.

The presence of anti-EA antibodies indicates acute or chronic active EBV infection and onset of viral replication. ${ }^{2}$ IgG Antibodies to EA were significantly more frequent among patients with multiple sclerosis than normal controls, compatible with the results reported by Sumaya et al. ${ }^{16}$ In the present study, two patients with multiple sclerosis and one control were anti-VCA IgM positive without clinical evidence of acute EBV infection. Further, the anti-EA response was independent of the initial course of the disease and the disease activity at the time of blood sampling. Taken together the results suggest that the patients with multiple sclerosis often have a chronic active form of the EBV infection, independent of the clinical course and activity of the disease.

No differences in antibody responses to other herpesviruses were found between the patients and controls. The prevalence of anti-HSV IgG antibodies was within the range of previous reports. ${ }^{14}{ }^{1924}$ The prevalence of anti-VZV IgG antibodies was higher than in most other studies, but confirms previous reports of no difference between the two groups. ${ }^{14} 1819$ Two previous studies of CMV IgG antibodies have shown higher frequency among the patients with multiple sclerosis than among controls, and ${ }^{14} 19$ one study found no difference between the two groups, ${ }^{18}$ compatible with the present study.

There may be several explanations for the EBV antibody pattern in the present study. It could reflect an altered immune response in multiple sclerosis or implicate EBV as an aetiological factor of the disease. An altered immune response to EBV in multiple sclerosis may reflect reduced supressor activity, which has been described in such patients. ${ }^{25}$ In addition, Craig et $a l^{26}$ have reported reduced $\mathrm{T}$ lymphocyte mediated control of B lymphocytes infected with EBV in patients with multiple sclerosis. This may lead to frequent reactivation of the latent EBV infection, which could explain the higher prevalence of EA antibodies in the patients with multiple sclerosis. Alternatively, EBV could induce demyelination in multiple sclerosis by local infection of oligodendrocytes or other glial cells leading to release of factors causing demyelination. However, there is no evidence for such a local EBV infection in the CNS of patients with multiple sclerosis. ${ }^{27}$ Demyelination by cross reacting autoantibodies is another theory. Our recent report of anti EBNA-1 antibodies cross reacting with antigens in neuroglial cells ${ }^{21}$ is compatible with this hypothesis. Furthermore, activation of autoreactive $\mathrm{T}$ lymphocytes by EBV supports the hypothesis that multiple sclerosis can be initiated by a ubiquitous infection in late childhood or early adolescence that induces an immunological response in genetically predisposed people. Such an activation could occur by EBV peptides that have sequence similarity with myelin epitopes (molecular mimicry) or by EBV superantigens. To our knowledge, there are no reports of EBV peptides as superantigens in multiple sclerosis, but there are findings that can support the theory of molecular mimicry. Two studies have reported peptide sequence identities between myelin basic protein and EBV, but these were computer analyses and did not take into account secondary and tertiary structures which are of importance in the immune response. ${ }^{28}{ }^{29}$ Of more interest is the report of Wucherpfennig et $a l^{30}$ that EBV mimicry peptides can activate myelin basic protein specific $\mathrm{T}$ cell clones.

The hypothesis of cross reacting autoantibodies and molecular mimicry is attractive, but substantial evidence that such mechanisms exist in multiple sclerosis has not yet been presented. Nevertheless, with reference to the anti-EBNA antibody results in the present study, it is of interest that Bray et $a l^{29}$ reported a higher frequency of anti-EBNA-1 antibodies in the CSF of patients with multiple sclerosis as well as peptide sequence identities between EBNA-1 and MBP.

A possible role of EBV infection in the complex pathogenesis of multiple sclerosis remains to be established, but the results in the present study indicate that EBV may participate in the development of the disease.

This work was supported by Kjell Almes Legacy and the Norwegian Society of multiple sclerosis. We thank Mrs Dagny Spissøy for excellent technical assistance.

1 Cook SD, Rohowsky-Kochan S, Bansil S, et al. Evidence for multiple sclerosis as an infectious disease. Acta Neurol Scan Suppl 1995;161:34-42.

2 Miller G. Epstein-Barr virus; biology, pathogenesis and medical aspects. In: Fields BN, Knipe DM, Chanock RM, et al, eds. Fields virology. New York: Raven 1990:192158.

3 Silverstein A, Steinberg G, Nathanson M. Nervous system involvment in infectious mononucleosis. Arch Neurol 1972: 26:353-8.

4 Bray PF, Culp KW, McFarlin DE, et al. Demyelinating disease after neurologically complicated primary Epstein-Barr ease after neurologically complicated primary
virus infection. Neurology 1992;42:278-82.

5 Operskalski EA, Visscher BR, Malmgren RM, et al. A case-control study of multiple sclerosis. Neurology 1989;39. case-con $825-9$.

6 Lindberg C, Andersen O, Vahlne A, et al. Epidemiological investigation of the association between infectious mononucleosis and multiple sclerosis. Neuroepidemiol 1991;10: $62-5$

7 Martyn CN, Cruddas M, Compston DA. Symptomatic Epstein-Barr virus infection and multiple sclerosis. F Neurol Neurosurg Psychiatry 1993;56:167-8.

8 Haahr S, Koch-Henriksen N, Møller-Larsen A, et al. Increased risk of multiple sclerosis after late Epstein-Barr virus infection: a historical prospective study. Multiple Sclerosis 1995;1:1-5.

9 Evans AS, Niederman JC. Epstein-Barr virus. In: Evans AS, ed. Viral infections of humans: epidemiology and control. New York: Plenum Medical Books 1989:265-92.

10 Alter M, Leibowitz U, Speer J. Risk of multiple sclerosis related to age at immigration to Israel. Arch Neurol related to age

11 Alter M, Okihiro $M$. When is multiple sclerosis acquired? Neurology 1971;21:1030-6.

12 Elian M, Nightingale S, Dean G. Multiple sclerosis among United Kingdom-born children of immigrants from the Indian subcontinent, Africa, and the West Indies. F Neurol Neurosurg Psychiatry 1990;53:906-11.

13 Sumaya CV, Myers LW, Ellison GW. Epstein-Barr virus antibodies in multiple sclerosis. Arch Neurol 1980;37: 94-6.

14 Bray PF, Bloomer LC, Salmon VC, et al. Epstein-Barr virus infection and antibody synthesis in patients with multiple sclerosis. Arch Neurol 1983;40:406-8.

15 Larsen PD, Bloomer LC, Bray PF. Epstein-Barr nuclear antigen and viral capsid antigen antibody titers in multiple sclerosis. Neurology 1985;35:435-8. 
16 Sumaya CV, Myers LW, Ellison GW, et al. Increased prevalence and titer of Epstein-Barr virus antibodies in patients with multiple sclerosis. Ann Neurol 1985;17: $371-7$

17 Shirodaria PV, Haire M, Fleming E, et al. Viral antibody titers. Comparison in patients with multiple sclerosis and rheumatoid arthritis. Arch Neurol 1987;44:1237-41.

18 Compston DA, Vakarelis BN, Paul E, et al. Viral infection in patients with multiple sclerosis and HLA-DR matched controls. Brain 1986;109:325-44.

19 Coyle PK, Sibony PA. Viral specificity of multiple sclerosis tear immunoglobulins. 7 Neuroimmunol 1987;14:197-203.

20 Vaughan JH, Riise T, Rhodes GH, et al. An Epstein-Barr virus related cross reactive autoimmune response in multiple sclerosis in Norway. 7 Neuroimmunol 1996;69:95-102

21 Riise T, Gronning M, Klauber MR, et al. Clustering of residence of multiple sclerosis patients at age 13 to 20 years in Hordaland, Norway. Am 7 Epidemiol 1991;133: 932-9.

22 McAlpine D. The benign form of multiple sclerosis. A study based on 241 cases seen within three years of onset and folbased on 241 cases seen within three years of onset and followed up until the

23 Kinnunen E, Valle M, Piirainen L, et al. Viral antibodies in multiple sclerosis. A nationwide co-twin study. Arch Neurol 1990;47:743-6.
24 Felgenhauer K, Schadlich HJ, Nekic M, et al. Cerebrospinal luid virus antibodies. A diagnostic indicator for multiple fluid virus antibodies. A diagnostic indi

25 Antel J, Arnason BGW, Medof ME. Supressor cell function in multiple sclerosis correlation with clinical disease activity. Ann Neurol 1979;5:338-42.

26 Craig JC, Haire M, Millar JH, et al. Immunological control of Epstein-Barr virus-transformed lymphocytes in multiple sclerosis. Clin Immunol Immunopathol 1983;29:86-93.

27 Hilton DA, Love S, Fletcher A, et al. Absence of Epstein-Barr virus RNA in multiple sclerosis as assessed by in situ hybridisation. I Neurol Neurosurg Psychiatry 1994;57:975-6.

28 Jahnke U, Fischer EH, Alvord EC Jr. Sequence homology between certain viral proteins and proteins related to encephalomyelitis and neuritis. Science 1985;229:282-4.

29 Bray PF, Luka J, Bray PF, et al. Antibodies against EpsteinBarr nuclear antigen (EBNA) in multiple sclerosis CSF, and two pentapeptide sequence identities between EBNA and myelin basic protein. Neurology 1992;42:1798-804.

30 Wucherpfennig KW, Strominger JL. Molecular mimicry in $\mathrm{T}$ cell-mediated autoimmunity: viral peptides activate $\mathrm{T}$ cell-mediated autoimmunity: viral peptides activate
human $\mathrm{T}$ cell clones specific for myelin basic protein. Cell 1995;80:695-705

\section{HISTORICAL NOTE}

\section{A note on the origins of syphilis}

Certain early writers suggested that syphilis infected ancient Chinese dynasties, whilst others claim priority for the afflicted populus of the early Romans, alleging that Augustus Caesar was afflicted by hereditary syphilis. But these suppositions are unconfirmed. The sailors with Columbus in 1493 were said to have brought the disease to Spain. It is certain that the Spanish fleet, when they fought for their ruler Alfonso II against the French forces of Charles VIII of France in 1494-5, heavily infected the peoples of Naples. The illness spread rapidly around Europe and mercenaries who in 1496 joined Perkin Warbeck in Scotland and with the support of James IV of Scotland invaded England, bore both arms and the grandgore (Old French. grand gorre: grand great + gorre syphilis) as it was called. ${ }^{1}$ In 1497 the Minutes of the Town Council of Edinborough ( Phil. Trans. XLII. 421) recognised: "This contagious sickness callit the Grandgor."

The infective and contagious nature of the disease were recognised. The Burgh of Aberdeen issued a ruling that "all licht (loose) women decist fra thar vicis and syne of venerie." A grandgore act was passed in September 1497. There was a suspected endemic of syphilis (treponarid) in 16 th century Norway. ${ }^{2}$

The name syphilis came into common usage. It came from a Latin epic poem Syphilis, sive Morbvs Gallicvs, written by Girolamo Fracastoro or Hieronymus Fracastorius(14831553). In his work De contagione et contagiosis morbis, he discussed the nature and the spread of infectious diseases, foretelling the germ theory of disease. A physician, astronomer, and poet of Verona, Fracastoro's poem was written in two volumes, 1525, and in a third published five years later. In 1686 Nahum Tate translated it with the title Syphilis: or, a Poetical History of the French Disease.. The term syphilis was employed systematically by Fracastoro in his treatise De Contagione ii. xi. (1546).

It tells the tale of a brave sailor who navigated a route westward from Spain to "a mighty island in the middle of the sea". The crew shot a flock of colourful birds on the island of Ophir, which belonged to the Sun God. One of the flock escaped and prophetically warned:

"Nor end your sufferings here; a strange

Disease,

And most obscene, shall on your Bodies seize ..."

In Book III, the subject of the poem, the shepherd Syphilus, blasphemes and offends the Sun God. He becomes the first sufferer of the disease.

“. . From whence this Malady its birth receiv'd,

And first th'offending Syphilus was griev'd, Who rais'd forbidden Altars on the Hill, And Victims bloud with impious Hands did spill;

He first wore Buboes dreadfull to the sight, First felt strange Pains and sleepless past the Night;

From him the Malady receiv'd its name." Book III, 321-32.

continued on page 547 